\title{
新潟県東頚城地域北部の中新・鮮新統の層序と年代
}

\author{
高野修*注1)・村松 敏雄**.小林 篇雄*
}

（平成元年 3 月 10 日受付， 5 月 23 日受理）

\section{Stratigraphy and Chronology of the Mio-Pliocene Series in the Northern Part of the Higashikubiki District, Niigata Prefecture, Central Japan}

By

\author{
Osamu TAKano, Toshio Muramatsu and Iwao Kobayashi
}

\begin{abstract}
The stratigraphical study of the Mio-Pliocene sedimentary rocks distributed in the Higashikubiki district, Niigata Prefecture, is important to make clear the geohistory of the northern Fossa Magna.

These rocks are divided into the Sugawa, the Tamugigawa, the Higashigawa Formations and the Uonuma Group in ascending order. The Sugawa Formation consists of massive siltstone. The Tamugigawa Formation is composed of sandstone, mudstone and flysh type alternation of sandstone and mudstone. The Tamugigawa Formation is further subdivided into four members, that is, the Lower, the Middle, the Upper and the Shobu mudstone Members. The Higashigawa Formation is composed of sandy siltstone. These formations conformably superpose each other.

The distribution of tephra marker beds in the Tamugigawa Formation indicates that the flysh type alternating beds of the Lower, the Middle and the Upper Members change laterally into the mudstone of the Shobu Member.

Nine tephrozones are discriminated on the basis of the lithology and frequency of marker tephra beds. All tephra beds range in composition from rhyolite to dacite, except for the tephrozone VII, which is composed of andesitic tephras and especially effective to the correlation of Mio-Pliocene strata in this area.

From the result of the F. T. dating of tuff layers and biostratigraphical data, each formation is correlative with the strata in the district of the Nishiyama Hill as follows; the Sugawa Formation with the Shiiya Formation, the Tamugigawa Formation with the Hamatsuda Formation, the Higashigawa Formation with the Nishiyama Formation.
\end{abstract}

\section{1.はじめに}

新潟県東䅡城地域には，新第三系中新統～第四系更新 統が広く分布する。これらの層序化関する研究は古くか ら行われているが (NODA, 1962; 新潟県, 1971; ほか), これらの層序は基本的に岩相区分化基づくものである。 近年, 新潟油田地域の西山層の上部・灰爪層・魚沼層は,

* 新潟大学理学部地質鉣物学教室

注1)(新所属・石油資源開発(侏探鉣部)

**新潟県教育センター
火山灭鍵層をつかった層序学的研究により, 上下の関係 でなく指交関係にある事実が解明され（安井ほか，1983; 菊池ほ加, 1984; 小林ほか, 1986; ほ加), 新潟地域の 新第三系について層序と対比の再検討が必要となってき ている。

今回筆者弓は, 新潟県東頝城地域北部( 松笩町一高柳 町), 石黒川流域周辺（図 1）の新第三系について, 岩 相層序・火山灰層序を検討し, 絶対年代の測定を行った のでここに報告する。とくに本報告においては，1）火 山灰層による同時間面の追跡に基づき，層相の側方変化 


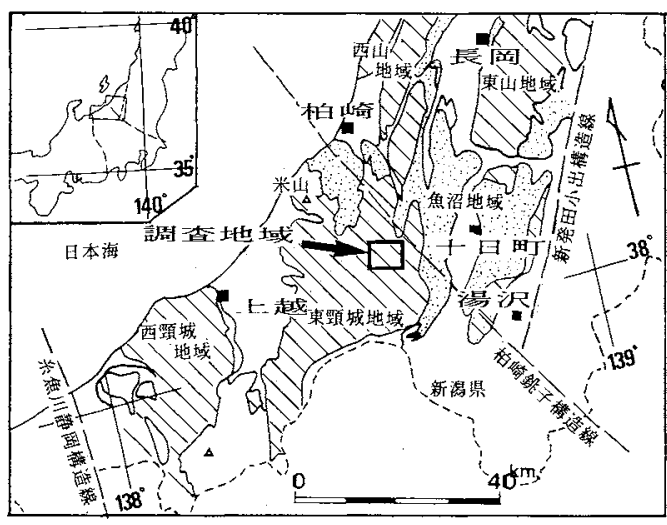

図1調査地域扔よび新潟県䅡城地方㧍よび周辺地域の 地質概略図。斜線部：中新一鮮新統分布域。打点 部：魚沼層群分布域

の解明に努めた。2）火山灰層の重鉱物組成の首位的変 化からテフロゾーン（黑川・沢栗，1984）を設定し，こ のゾーンが近接地域における対比の際に有効であること を示した。3）火山灰層中のジルコンを用いるフィッショ ントラック法によって絶対年代を求めた。4）本地域で の微化石層序の資料老加元, 岩相 - 火山灰・年代の各層 序を総括した。

その結果として，以下のことが明らかとなった。本調 查地域に分布する新第三系は中新統最上部〜鮮新統であ り，新潟標隼層序の椎谷層加西山層に対比される。鍵 層となる火山灰層が広く追跡され，砂岩・泥岩の互層と 泥岩を主体とする地層とが大きく指交関係にある。

今回の研究は，地質調查・岩相層序については高野・ 小林が，火山灰分析については高野が，フィッション・ トラック法年代測定については松村がそれぞれ担当した。

\section{2. 地質各説（岩相層序）}

本地域に分布する中新一鮮新統は，下位より須门罢層・ 态考川累層・染川累層・魚沼層群に区分され，すのて 整合関係にある（図 2，3）。このうち，田麦川累層は 4 部層に区分される。本地域の地質図を図 2 に示す。な 抒，魚沼層群については記載を省略する。

\section{1 須川累層}

<命名〉 新潟大学東搷城地域地質調查グループ(1987)。 <模式地〉 東䅡城郡安塚町須川の須川川沿い(地域外)。 <層厚> 石黒川流域で $150 \mathrm{~m}+$ 。 〈分布〉 本調查地域内では, 高柳町石黑の石黑背斜軸 部之，菘代町寺田付近の儀明背斜軸部に分布する。

く層相〉おもに塊状泥岩からなる。やや青みを帯びた 暗兏色を呈し，風化すると鱗片状に細汃く砕ける性質が ある。直径10-15cm の疑灰質シルトノジュールを含む。

\section{2 田麦川累層}

〈命名〉 新潟大学東頝城地域地質調查グループ(1987)。 <模式地〉 東頝城郡大島村板山付近の田麦川沿い。 〈分布〉 本調查地域内では，大島村田麦加ら石黒背斜 两翼部に加けて広く分布する。

田麦川累層は, 層相により下部・中部・上部招よび坦 浦泥岩部層に分けられる。下部層・中部層・上部層は夕一 ビダイトの特徵を持つ砂岩泥岩互層相からなり, 菖蒲泥 岩部層は塊状泥岩相からなる。下部・中部・上部の砂岩 泥岩互層相は葛蒲泥岩部層の泥岩相と指交関係にある （図 4）。本論では，高柳町の石黒川ルート（ルートNo. 48）（図 4）を模式ルートと定め，これと松代町西部地 域の鯖石川ルート（ルートNo．11）（図 3，4），および 調查地域南西方にある田麦川累層の模式地の田麦川ルー ト（ルートNo. 30）（図 3）との岩相を比較しながら 層相の記載を行う。

\section{2 .1 田麦川累層下部}

<層厚〉 石黑川地域で $100-500 \mathrm{~m}$ 。

〈下位層との関係＞石黑川ルートでは，高柳町石黒集 落付近の石黑背斜朝部に分布する須川累層の塊状泥岩の 上に重なる砂岩泥岩互首の基底を下限とする。

〈層相〉 本部層は, タービダイトの特徽を持っ厚層砂 岩と砂岩泥岩互層を主体とする。

田麦川累層の模式地の田麦川地域では，厚層砂岩層之 火山灰鍵層に着目すると，下位上り $\mathrm{Tl}-\mathrm{A} \cdot \mathrm{B} \cdot \mathrm{C} \cdot \mathrm{D} \cdot \mathrm{E} \cdot \mathrm{F} \cdot$ $\mathrm{G} \cdot \mathrm{H}$ の 8 つのニニット分けられる（高野、投稿 中)。 $\mathrm{Tl}-\mathrm{A} \cdot \mathrm{C} \cdot \mathrm{E} \cdot \mathrm{G}$ はそれぞれりズミックな砂岩泥岩互 層からなる。 $\mathrm{Tl}-\mathrm{B} \cdot \mathrm{D} \cdot \mathrm{F} \cdot \mathrm{H}$ はそ机ぞれ厚層砂岩層から なる。厚層砂岩層は層厚50-200m で，招当に塊状の細 粒砂や極細粒砂加らなり，中～細磁層や含磁泥岩層を挟 む。

模式地の田麦川流域に比べて，石黒川地域・松代西部 地域では, 泥岩相（苔蒲泥岩部層）への移行が著しい。

石黒川地域では石黑背斜の西翼と東翼とで層相が異な る。石黑背斜の東翼では葛蒲泥岩部層が卓越するが，石 黒背斜西翼では砂岩泥岩互層が卓越する。松代町西部地 域では，泥岩相への移行が最む著しく，Tl-D に対応す ると考えられる砂岩泥岩互層と砂質シルト岩のみが分布

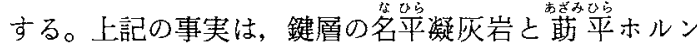
ブレンド疑灰岩の連続によって確かめられる（困 2，3， 4)。

\section{2 .2 田麦川累層中部}

<層厚〉 石黑川流域で $270 \mathrm{~m} 。$

〈下位層との関係＞石黑川ルートでは，高柳町石黒集 落付近に分布する菖蒲泥岩部層の上位に重なる砂岩層の 


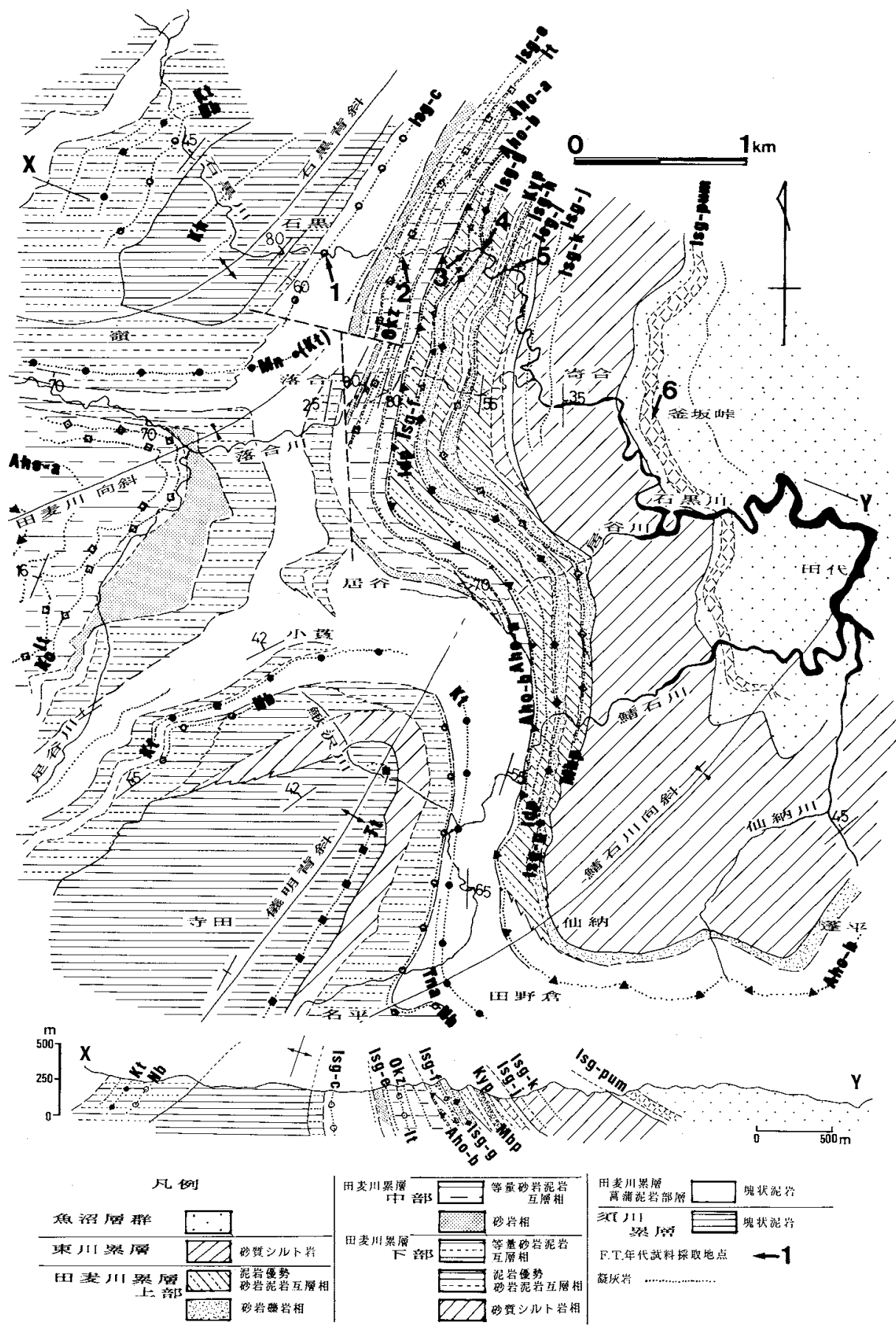

図 2 新潟県東頝城地域北東部松代町〜高柳町付近の地質図括よび地質断面図。 火山死(凝灰岩) 鍵首略号の説明は本文参照 
基底をむって中部層の基底とする。

〈層相〉本部層はリズミックなフリッシュ型等量仯岩 泥岩互層相を主体とし，砂岩相を挟む。

層相之火山灰鍵層に基づいて,下位より $\mathrm{Tm}-\mathrm{I} \cdot \mathrm{J} \cdot \mathrm{K} \cdot \mathrm{L} \cdot$ Mの5つのユニットに区分される（図 3)。

石黒川地域では次のような層相からなる。Tm-I は泥 岩優势の仯岩泥岩互層相加らなる上部ほど砂岩の層厚 が厚い。Tm-さは，塊状砂岩相からなりシルト岩薄層を 挟む。 Tm-K は等量砂岩泥岩互層相之塊状泥岩相加 なる，鍵層の Isg-e を挟む。Tm-L は等量砂岩泥岩互層 相からなり，層厚約 $1 \mathrm{~m}$ の塊状砂岩層を挟む。基底に板 山凝灰岩層を挟む。 $\mathrm{Tm}-\mathrm{M}$ は等量および泥岩優勢の 砂岩泥岩互層相からなり, 層厚数 $\mathrm{m}$ の塊状砂岩層を 挟む。基底に助平ホルンブレンド疑质岩 - $\mathrm{a}$ 層を挟む。
松代町西部地域では，本部層層準はすべて葛蒲泥岩部 層の泥岩相に移化する。

\subsection{3 田麦川累層上部}

<層厚〉石黒川流域で $350 \mathrm{~m}$ 。

〈下位層との関係＞ 鍵層の莇平ホルンブレンド凝灰 岩- $\mathrm{b}$ の基底をむって中部層との境界とする。

〈層相〉＼cjkstart本部層は泥岩優勢砂岩泥岩互層相を主体とし, 泥岩層や砂岩層・䃋岩層を挟む。

層相と火山灰鍵層を屯とに, 下位より $\mathrm{Tu}-\mathrm{N} \cdot \mathrm{O} \cdot \mathrm{P} の$ 3つのユニットに区分される(図 3)。

石黑川地域では，次のような層相からなる。Tu-N は 泥岩優勢秒岩泥岩互層相之砂岩相からなる。層厚数10一 $200 \mathrm{~cm}$ の碩岩層を挟む。居签凝灰岩が挟まれる。Tu-O は砂質ノジュールを含を細粒一粗粒塊状砂岩相からなる。

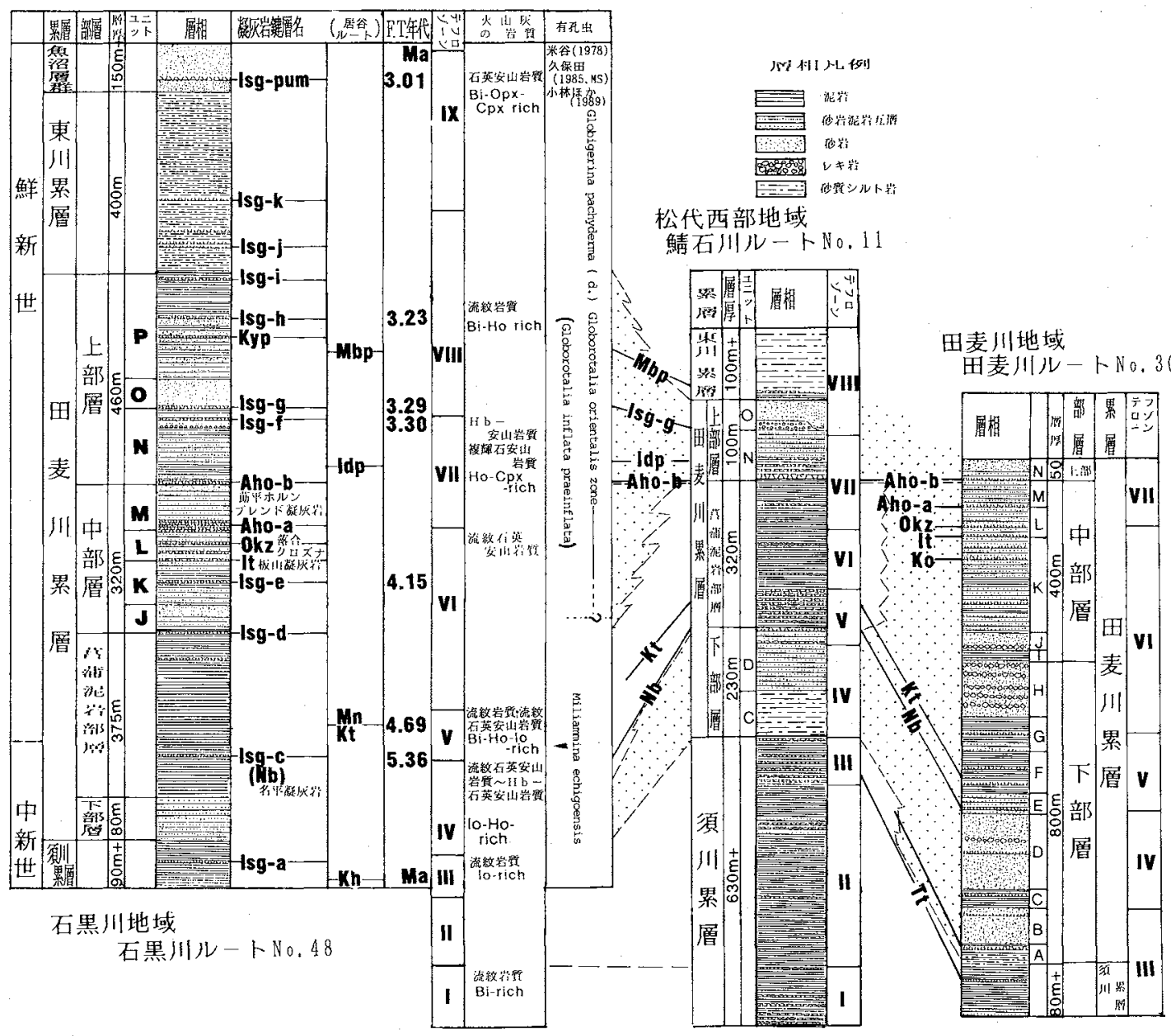

図 3 調查地域のルート別地質柱状図およびテフロゾーンの分帯 


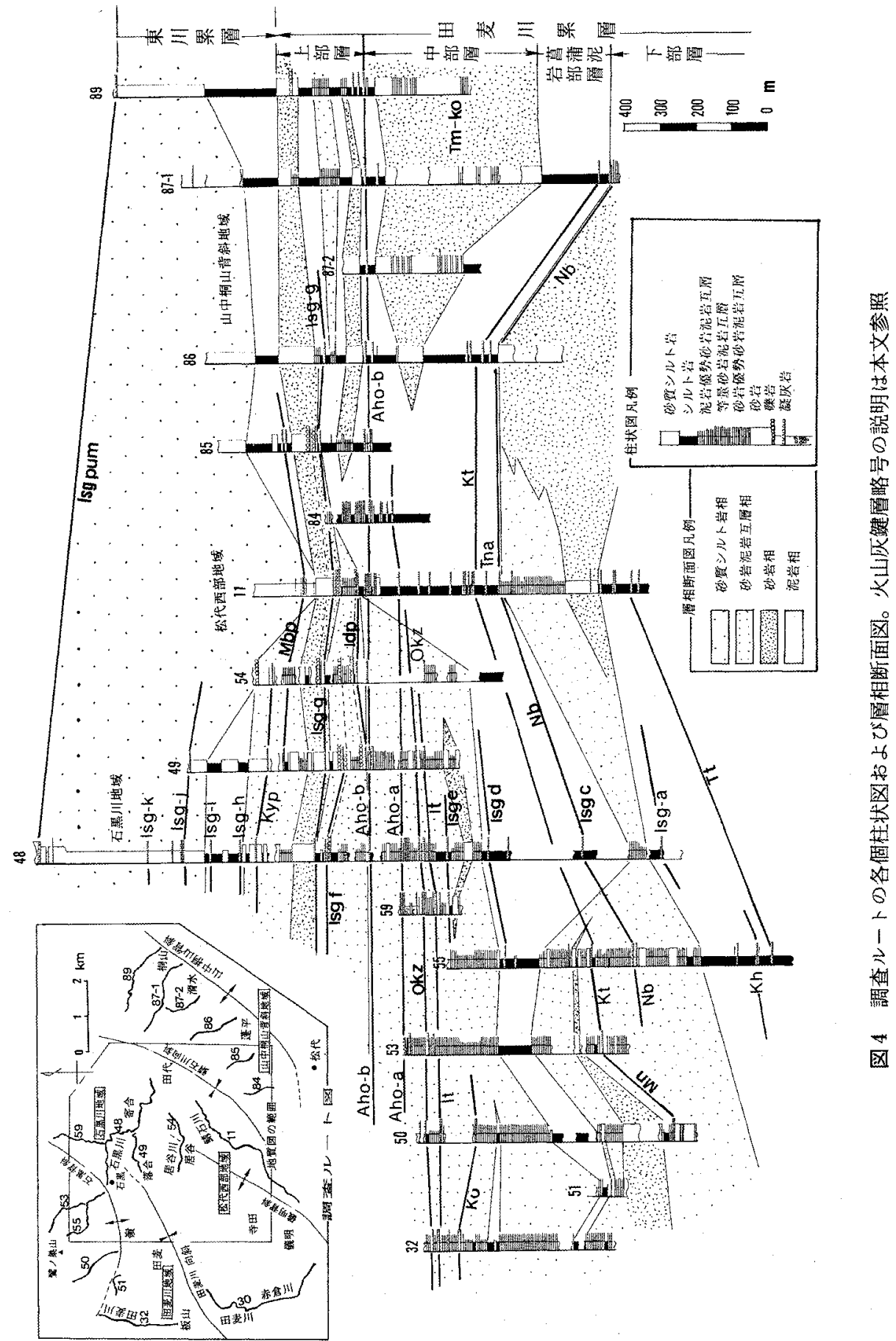


厚い礫岩層が挟まれ，Umbonium sp，を多産する。 基底にIsg-g が挟まれる。Tu-P は塊状砂岩相・泥 岩相怙よび砂岩泥岩の細互層相からなり, 紅葉橋凝灭岩 層 $(\mathrm{Mbp}) \cdot$ 上㝒合疑灰岩層 $(\mathrm{Kyp})$ を挟む。

\subsection{4 苔蒲泥岩部層（再定義）}

<再定義〉 松代西部地域加東頚城地域南方に㕕く分 布する黒灰色塊状泥岩を田麦川累層苔蒲泥岩部層々再定 義する。本部層は, 新潟大学東頝城地域地質調查グルー プ（1987）の菖蒲累層に相当するが，本調查地域では， 田麦川累層下部・中部・上部之複雑に指交するため, 田 麦川罢層中の泥岩部層として再定義する。名平凝灰岩, 小貫凝灰岩，莇平ホルンブレンド凝死岩一bの連続によっ $\tau$, 田麦川累層下部層・中部層・上部層之同時異相の関 係にあることが確認される。

〈模式地〉 松代町田野倉の鯖石川沿い。

$<$ 層厚 $>0-600 \mathrm{~m}$ 。

〈分布〉，石黒背斜東翼加ら松代西部地域の儀明背斜東 翼にかけて分布する。

〈層相〉やや青みを带びた暗灰色を呈する塊状泥岩か らなる。まれに極細粒砂岩の薄層を挟卆。

\section{3 東川累層 (NODA, 1962)}

<模式地〉 松之山町赤倉付近の東川沿い（地域外）。

〈分布〉 調查地域内では鯖石川向斜周迅部。

<層厚> 石黒川流域で $400 \mathrm{~m}$ 。

〈下位層との関係> 石黒川ルートでは高柳町寄合付近 に扔いて, 田麦川累層上部の砂岩相・泥岩相が, 完全に 砂質シルト岩相に变化する層準をもって田麦川累層との 境界とする。

〈上位層との関係〉 上位の魚沼層群とは漸移的であり， 砂質シルト岩が除々に粗粒化し, 砂岩に移行する。完全 に砂岩に移行した層準をすって魚沼層群との境界とする。 〈層相〉お机淡灰色砂質シル卜岩からなる。褐鉄鉱 におおわれたノシュールが $10-20 \mathrm{~cm}$ の間隔をおいて層 状に配列する特徴的な岩相を呈する。

\section{3. 火山灰層分析}

火山灰層は，1）層序を編む上での鍵層となる，2）岩 質から火山活動を推定できる，3）含有物質から F. T. 年代を推定できる,などの点から重要である。本研究で あ, これらの火山灰層の持つ特性を生加すために, 層序 を編む上でのひとつの示準になる向のとして, 火山灰層 の研究を行った。

今回の研究では, 高柳町の石黒川ルート（図 3,4$)$ を主調查ルートとし，連続性のよい火山灰層を記載した。 新潟大学東䅡城地域地質調查グループ（1987）の報告が あるあのについては，細かい記載を省略した。

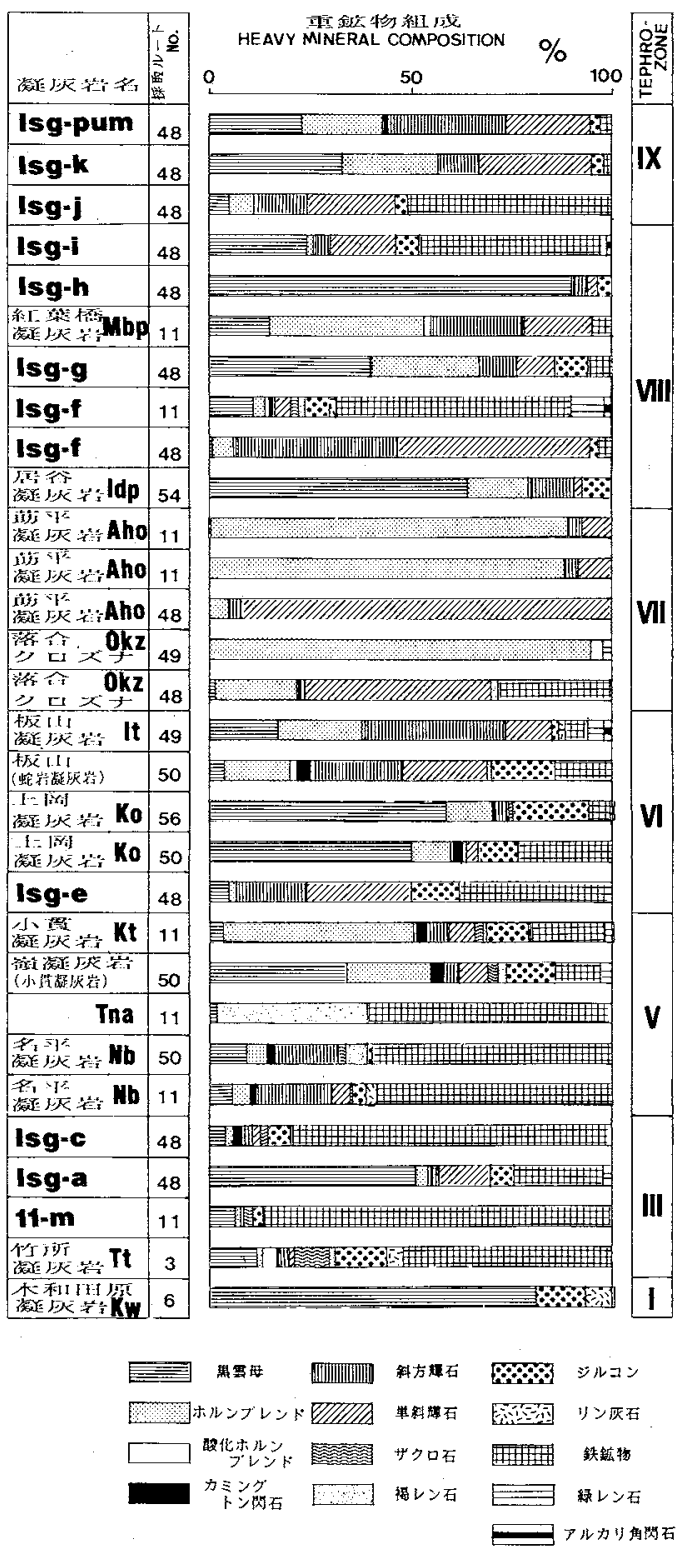

図 5 調查地域の主な火山灰層の重鉱物組成（個数\%)。 採取ルートの番号は図 4 の調查ルート図参照, 但 し，3，6，56のルートは図 4 の範囲外。

なお，重鉱物組成の分析は次の方法による。

試料を水洗，乾燥，笠別し，細粒砂サイズ $(1 / 4-1$ $/ 8 \mathrm{~mm})$ および極細粒砂サイズ $(1 / 8-1 / 16 \mathrm{~mm})$ に ついて重鉱物を分離し，バルサムでプレパラートに封入 した。両サイズごと 200 粒以上を同定し，両者の平均を とって，重鉱物組成とした（図 5)。

さらにこの結果から，重鉱物組成中の黑雲母十褐レン 


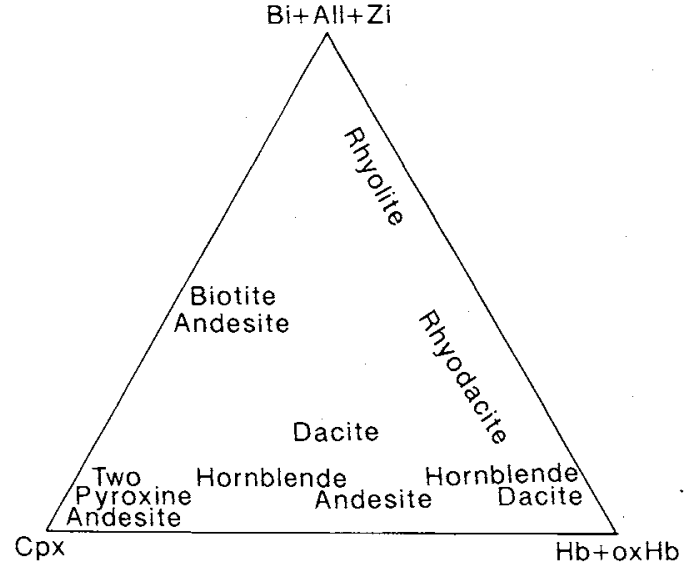

図 6 火山兏層の岩質を推定する BHC 図（黒川・沢 栗, 1984)。各火山乍層の重鉱物組成のうち, 黒 雲母十ジルコン+褐レン石，ホルンブレンド+酸 化ホルンブレンド・単斜輝石の割合からダイヤグ ラムにプロットされる位置によって岩質が推定さ れる。
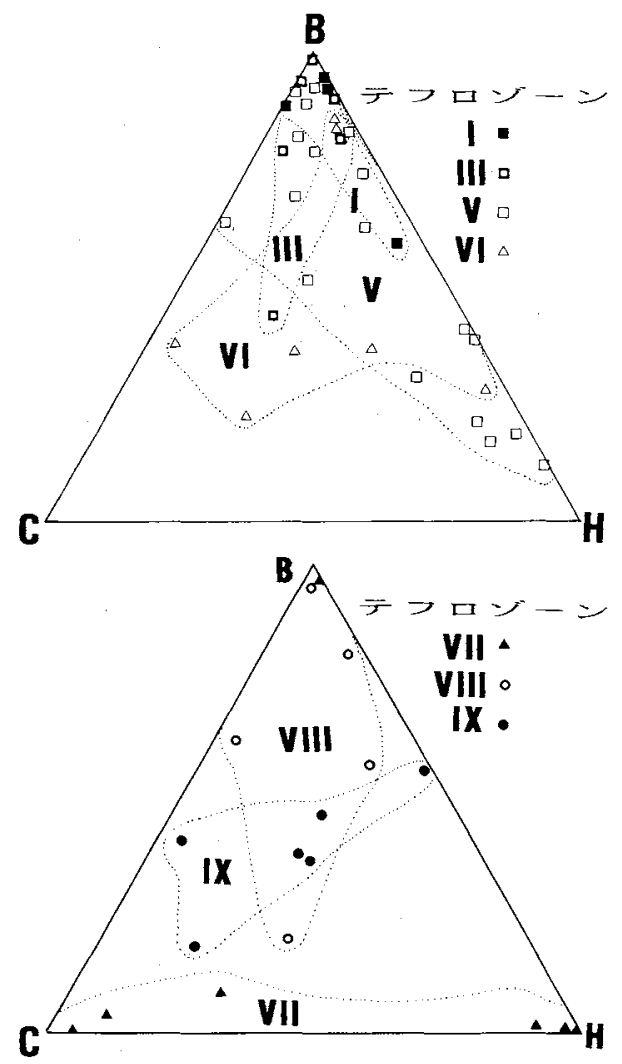

図 7 テフロゾーン別に火山灭層を BHC 図にプロット した瓦

石+ジルコン・ホルンブレンド+酸化ホルンブレンド・ 単斜輝石の量比に基づく $\mathrm{BHC}$ 図（図 6; 黒川・沢栗, 1984）によってその火山灰の岩質を推定した。

\section{1 火山灰層記載}

本調查地域の須川層上部より上位に挟まれる代表的な 鍵層となる火山兏層について記載する。

1）香和田原凝洟岩 $\mathrm{Kw}$ （新潟大学東頚城地域地質 調查グループ, 1987)。

〈模式地〉 松代町木和田原の沢沿い（地域外）。

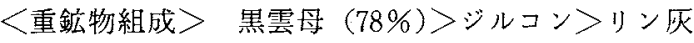
石。

2）竹所凝灰岩 $\mathrm{Tt}$ (新潟大学東頝城地域地質調查グ ループ, 1987)。

<模式地〉 松代町濁川ルート（地域外）。

〈層相・層厚〉白色ガラ又質火山疢からなる。220cm。 <重鉱物組成・岩質〉 鉄鉱物》黑雲母。流紋岩質。

3）入山川凝灰岩 $\mathrm{Ir}$ (新称)

〈模式地〉大島村岩倉の入山川（地域外）。

〈層相・層厚〉白色中粒一細粒の軽石質火山灰からな る。層厚は模式地では $60 \mathrm{~m} 。$

4) Isg-a (新称)

$<$ 模式地〉 高柳町石黑川（図 2)。

〈層相・層厚〉 灭色, 極細粒砂サイズで,やや砂質, ガラス質。ゴマシオ状。層厚 $5 \mathrm{~cm}$ 。

〈重鉱物組成・岩質〉 黒雲母 $(52 \%) \gg$ 鉄鉱物〉単斜 輝石。流紋岩質。

5) 名平凝灰岩 (Isg-c) $\mathrm{Nb}$ （新潟大学東頝城地域 地質䛇查グループ，1987）

〈模式地〉松代町名平加ら田野倉までの林道沿い。 〈層相 - 層厚〉 淡灰色一白色, 塊状, 中粒一細粒サイ ズの軽石質火山灭。黑雲母・鉄鉱物が目立つ。層厚80 $\mathrm{cm}_{\circ}$

〈重鉱物組成・岩質〉 鉄鉱物（80\%）がほとんどを占 める。ほかにジルコン・黒雲母などを含む。流紋眙質。

6) 嶺凝灭岩 $\mathrm{Mn}$ (新称)

<模式地〉大島村嶺加ら藤尾間の道路沿い。

〈層相・層厚〉 中粒の軽石質火山兏からなる。全体に 平行葉理が発達しており，シルトの薄層が挟まれること がある。下部ほど軽石質，上部ほど仯質で有色鉣物が目 立つ。層厚 $8 \mathrm{~m}$ 。

〈重鉱物組成・岩質〉 黒雲母 $(35 \%)>$ \ルンブレン

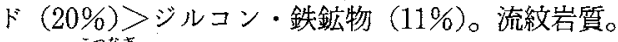

7) 小貫凝死岩 Kt（新潟大学東頚城地域地質調查グ ループ, 1987)

〈模式地〉 松代町小貫の国道353号線沿い。 〈対比〉嶺凝兏岩と小貫凝死岩は対比される。

8) Isg-d (新称)

<模式地〉 高柳町石黑川（図 2)。

<層準〉 田麦川累層中部層 Tm-J O基底。 
＜層相・層厚＞灭色から暗灰色のシルトサイズのガラ 不質火山灰からなる。有色鉱物をほとんど含まない。上 部はシルトと湿交し，級化する。層厚 $70 \mathrm{~cm}$ 。

9) Isg-e (新称)

<模式地〉 高柳町石黑川。

〈層準〉田麦川累層中部層 $\mathrm{Tm}-\mathrm{K}$ に挟まれる。

〈層相・層厚〉白色一淡灰色の細粒加ら中粒の軽石質 火山灰からなる。黒雲母結晶が目立つ。級化構造がみら れる。層厚 $80 \mathrm{~cm}$ 。

<重鉱物組成・岩質〉 鉄鉱物 $(38 \%)>$ 単斜輝石 (27

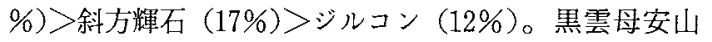
岩質。

以上 $6,7,8,9$ は田野倉凝灭岩ゾーン（新潟大学東 頝城地域地質調查グループ，1987）に含まれる。

10）板山凝灰岩 It（新潟大学東頝城地域地質調查グ ループ, 1987)。

<模式地〉大島村板山の板山不動尊（地域外）。 <層準〉 田麦川累層中部層 $\mathrm{Tm}-\mathrm{L}$ の基底。

〈層相・層厚〉 白色の軽石質火山灰からなり, 固結度 が高い。スランプ構造が発達する。首厚 $500-700 \mathrm{~cm}$ 。

〈重鉱物組成・岩質〉 ホルンブレンド $(39 \%) \cdot$ 鉄鉱 物 $(31 \%)>$ 黒雲母-単斜輝石 $\cdot$ 斜方輝石。石英安山岩 質。

11）落合クロズナ凝死岩 $\mathrm{Okz}$ (新称)

<模式地〉 高柳町落合の落合川沿い（図 2)。

<層準〉田麦川累層中部層 Tm-L 板山凝灰岩の直上。 <層相・層厚〉 細粒一粗粒砂サイズで黑色の火山岩片 と，有色銀物粒加らる。層厚 $5-10 \mathrm{~cm}$ 。

〈重鉱物組成・岩質〉 ホルンブレンド $(90 \%) \gg$ 》斜方 輝石。ホルンブレンド石英安山岩質。

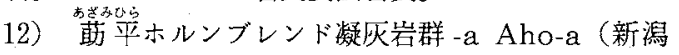
大学東頝城地域地質調查グループ，1987を再定義）

〈再定義〉層厚約 $20 \mathrm{~m}$ にわたって単層厚 $10-40 \mathrm{~cm}$ の 同質凝灰岩が 1 8 枚挟まれるゾーンが，2 層準認めら れる。下位より Aho-a，-bとする。

〈模式地〉高柳町石黒川（図 2)。

<層準〉 田麦川罢層中部層 $\mathrm{Tm}-\mathrm{M}$ 。

13）莇平ホルンブレンド凝灰岩群 - b Aho-b

<模式地〉 松代町莇平の觛石川（図 2)。

<層準> 田麦川累層上部層 Tu-N。

〈分布〉本地域抢よび周辺地域にわたって広く連続し， 調查地域北方では黒姫累層（小林ほか，1989）の火砕岩 類に連続する。

〈層相〉 ホルンブレンドや単斜輝石の自形結晶が目立 つ火山磂加らなる。黒灰色。

〈重鉱物組成・岩質〉それぞれの層によって，ホルン
ブレンドと単斜楎石の量比が異なる。

·sp. 1 単斜輝石 $(93 \%) \gg$ ホルンブレンド $(5 \%)$ 。

-sp. 2 ホルンブレンド $(86 \%) \gg$ 単斜輝石 $(10 \%)$ 。

複輝石安山岩質・ホルンブレンド石英安山岩質。

14）居谷軽石質凝灰岩 Idp（新称）

<模式地〉 高柳町居谷の居谷川沿い（四 2)。

＜層準〉田麦川累層上部 Tu- $\mathrm{N}$ に挟まれる。

〈層相・層厚〉白色の中粒加ら粗粒の軽石質火山灰加 らなる。黒雲母結晶が目立つ。層厚 $40 \mathrm{~cm}$ 。

〈重鉱物組成・岩質〉 黒雲母 $(64 \%) \gg$ ホルンブレン

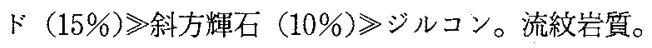

15) Isg-f (新称)

<模式地〉 高柳町石黑川。

＜層準＞田麦川累層上部 Tu-N に挟まれる。

〈層相・層厚〉 細粒の砂質結晶質火山灭からなる。 有色鉱物が多く含まれ，ゴマシオ状。全体に平行ラミナ がみられ，級化構造が発達する。層厚 $22 \mathrm{~cm}$ 。

〈重鉱物組成・岩質〉 単斜輝石 $(51 \%)>$ 斜方輝石 (40 \%)》ホルンブレンド。複輝石安山岩質。

16) Isg-g (新称)

<模式地〉 高柳町石黒川。

<層準〉 田麦川累層上部 $\mathrm{Tu}-\mathrm{O}$ 基底。

〈層相・層厚〉 白色中粒一粗粒軽石質火山灰からなり， 黒雲母が顕著に含まれる。塊状で，下半部が逆級化し上 半部で正級化する。層厚 $140 \mathrm{~cm}$ 。

〈重鉱物組成・岩質〉 黒雲母 $(40 \%)>$ ホルンブレン ド $(27 \%)>$ 斜方輝石 $(10 \%)$ - 単斜輝石 $(9 \%)$ 。流紋岩 質。

17）紅葉橋軽石質凝灰岩 $\mathrm{Mbp}$ (新称)

<模式地〉 松代町莇平の鯖石川。

<層準〉田麦川累層上部 Tu-P の基底。

〈層相〉白色の中粒一粗粒の軽石質火山灰からなる。 砂質シルト岩と互層をなす。

18）上寄合凝灰岩 $\mathrm{Kyp}$ (新称)

$<$ 模式地 $>$ 高柳町石黒川。

<層準〉 由麦川累層上部 Tu-P。

〈層相・層厚〉 淡灰色の極細粒からシルトサイズの軽 石一ガラス質火山灰からなる。塊状。首厚 $150 \mathrm{~cm}$ 。

19） Isg-i (新称)

$<$ 模式地〉 高柳町寄合の石黒川。

〈層準〉田麦川累層の最上部 Tu-P。

〈層相・層厚〉やや砂質なガラス質一結晶質火山灰。 細粒一極細粒で，有色鉱物が目立つ。層厚 $15 \mathrm{~cm}$ 。

〈重鉱物組成・岩質〉 鉄鉱物 (48\%) >黒雲母 $(25 \%)>$

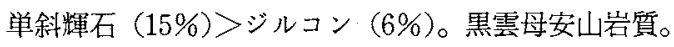

20) Isg-j (新称) 
<模式地> 高柳町寄合の石黒川。

$<$ 層準〉 東川累層。

〈層相・勫厚〉 極細粒からシルトサイズの淡灰色ガラ 又質火山灰からなる。有色鉱物は目立たない。層厚16 $\mathrm{cm}_{\mathrm{O}}$

〈重鉱物組成・岩質〉 鉄鉱物 $(52 \%)>$ 単斜輝石 $(22$ $\%)>$ 斜方輝石 $(13 \%)>$ ホルンブレンド。石英安山岩質。

21) Isg-k (新称)

$<$ 模式地 $>$ 高柳町寄合の石黑川。

$<$ 層準〉 東川累層。

〈層相・層厚〉 細粒淡兏色軽石質火山灰加らなる。有 色鉱物が顕著にみられる。レンズ状に挟まれる。

<重鉱物組成・岩質〉 黒雲母 $(33 \%)>$ 単斜輝石 $(27$ $\%)$ ・ホルンブレンド $(24 \%)>$ 斜方輝石 $(10 \%)$ 。石英 安山岩質。

22）石黒川軽石質凝灰岩 Isg-pum（新称）

〈模式地〉 高柳町石黒川流域釜坂峠付近（図 2)。 $<$ 層準〉 魚沼層群基底部付近。

〈層相・層厚〉白色の粗粒加ら中粒の軽石質火山灰か らなる。模式地では，層内にスランプ構造がみられる。 部分的に平行葉理が発達し，砂や磁と混交する。模式地 では層厚 $30 \mathrm{~m}+。$

$<$ 重鉱物組成・岩質> 斜方輝石 $(30 \%)>$ 黒雲母（23 $\%)>$ 単斜輝石・ホルンブレンド $(20 \%)$ 。石英安山岩質。

\section{2 テフロゾーンの設定}

テフロゾーン（吉川, 1976; 黒川・㳄栗, 1984）とは, 火山曱を挟む頻度，火山灰の岩質などに基づいて地層を 分帯するもので，地層の対比に有效である。

本地域の中新一鮮新統は，下位より I-IX の9つの テフロゾーンに分帯される（図 3)。以下，各テフロゾー ンについて簡単に特徴を述べる。

1）テフロゾーン I : 須川累層下部。木和田原凝网岩 を含む白色ガラス質火山成層を多く含むゾーン。黑雲母・ 鉄鉱物に富む。流紋岩質。

2）テフロゾーンII：須川累層中部。火山庅層をあま り含まないゾーン。

3）テフロゾーン III : 須川累層最上部一田麦川累層下 部層 TI-A，-B。竹所凝灭岩を含む白色ガラ又質・軽石 質火山灰層を多く挟むゾーン。鉄鉱物に富む。流紋岩 質。

4）テフロゾーン V : 田麦川累層下部層 Tl-C Tl-D。 火山灰層をあまり含まないゾーン。火山兏層には，ホル ンブレンド・鉄鉱物が多く含まれる。流紋石英安山岩質 （沢栗・黑川，1984）－角閃石石英安山岩質。

5）テフロゾーン V : 田麦川累層下部層 $\mathrm{Tl}-\mathrm{E} \sim \mathrm{TI}-\mathrm{G}_{0}$ 田野倉凝兏岩ゾーン・名平凝灰岩・小貫凝灰岩・領
凝灭岩・Isg-c を含む白色ガラス質・軽石質火山灰層が 多く挟まれるゾーン。黑雲母・ホルンブレンド・鉄鉱物 に富む。流紋岩質－流紋石英安山岩質（沢栗・黑川， 1984)。

6) テフロゾーン VI : 田麦川罢層下部層 TI-G〜中部 層 Tm-L. Isg-d・Isg-e ・板山凝灰岩を含むゾーン。火 山灰層が挟まれる頻度は中程度。流紋岩質一石英安山岩 質。

7）テフロゾーン VII：田麦川累層中部缯 $\mathrm{Tm}-\mathrm{L} \sim$ 上 部層 Tu-N。調查地域北力の黒姫山火砕岩類の層準であ る。莇平ホルンブレンド凝灰岩・落合クロズナ凝兏岩な ご，角閃石複輝石安山岩質スコリア火山在層を頻繁に挟 むゾーンで，ホルンブレンド・単斜輝石に富む。ホルン ブレンド安山岩質一複輝石安山岩質。

8）テフロゾーン壮：田麦川累層上部層 $\mathrm{Tu}-\mathrm{O} \sim$ 東川 累層中部。Isg-g・Isg-h・Isg-i を含む白色軽石質・ガラ 不質火山灰層を中程度の頻度で挟むゾーン。黒雲母に富 む傾向がある。流紋岩質－石英安山岩質一黒雲母安山岩 質。

9）テフロゾーン IX : 東川累層中部〜魚沼層群最下部。 Isg-j·Isg-k·Isg-pum なよ゙，白色ガラス質・軽 石質火山灰層を中程度の頻度で挟むゾーン。斜方 輝石に富む傾向があり，ほかにホルンブレンド・ 黒雲母・单斜輝石が多く含まれる。流效岩質。

\section{4. フィッショントラック法による絶対年代}

\section{1 方 法}

高柳町石黒川流域に露出する火山灰層の中で, とく に黒雲母・ジルコンを多く含む6枚の軽不質火山兏層 (Isg-c·Isg-e Isg-f $\cdot$ Isg-g・Isg-h・Isg-pum) 加ら試料 を採取した。

手法として, Grain by grain 法十外部ディテクター 法（S2 $\pi \mathrm{ES}-\mathrm{I} 2 \pi \mathrm{ED}$ 法）を採用した。自発飛跡はジ ルコン自体から，誘発飛跡はディテクターとして貼 付した白雲母から計测した。ジルコンのエッチングは, GLEADOW et al. (1976) にしたがい, KOH(5.7g)+ $\mathrm{NaOH}(4 \mathrm{~g})$ の共融液を用い, $230^{\circ} \mathrm{C}, 15-20$ 時間の条 件下で行った。白雲母のエッチングは $46 \% \mathrm{HF}, 20^{\circ} \mathrm{C} の$ 条件下で，10分間行った。

また，試料への熱中性子線量 $(\phi)$ の测定には，NBCSRM962a の標準ガラスを使用した。熱中性子照射には, 東海村原子力研究所のJR4 実験用原子炻を便用した。 なお，SRM962aのB值は6.67 × $10^{9} \mathrm{n} / \mathrm{s}$ を採用した。

また， ${ }^{238} \mathrm{U}$ の自発核分裂の壊変定数では， $\lambda_{\mathrm{f}}=6.85$ $\times 10^{-17} / \mathrm{y}$ を用いたので, 年代 (T) を算出する式は次 のようになる。 
表 1 フィッショントラック法による年代測定結果

\begin{tabular}{|c|c|c|c|c|c|c|c|c|c|c|}
\hline \multirow{2}{*}{$\begin{array}{l}\text { 試 } \\
\text { 号 }\end{array}$} & \multirow{2}{*}{$\frac{\text { 料 }}{\text { 凝灭岩名 }}$} & \multicolumn{2}{|c|}{ 自発飛 跡 } & \multicolumn{2}{|c|}{ 誘 発 飛 跡 } & \multirow{2}{*}{$\begin{array}{c}\text { 熱中性子 } \\
\text { 線量 } \\
\left(\times 10^{11} / \mathrm{cm}^{2}\right)\end{array}$} & \multirow{2}{*}{$\begin{array}{l}\text { ジルコ } \\
\text { 擞 }\end{array}$} & \multirow{2}{*}{$\begin{array}{c}\text { F.T.年代 } \\
(\mathrm{Ma})\end{array}$} & \multirow{2}{*}{$\begin{array}{l}\text { 詔差 } \\
(\mathrm{Ma})\end{array}$} & \multirow{2}{*}{$\begin{array}{l}\text { ウラン } \\
\text { 含有量 } \\
\text { (ppm) }\end{array}$} \\
\hline & & $\rho_{\mathrm{S}}\left(\times 10^{5}\right)$ & $\mathrm{Ns}$ & $\rho \mathrm{i}\left(\times 10^{6}\right)$ & $\mathrm{Ni}$ & & & & & \\
\hline SP O 1 & Isg-pum & 2.18 & 313 & 2.21 & 3174 & 4.98 & 37 & 3.01 & 0.19 & 225 \\
\hline $\mathrm{SP} O 2$ & Isg-h & 2.7 & 351 & 2.62 & 3316 & 4.98 & 35 & 3.23 & 0.19 & 252 \\
\hline $\mathrm{SP} O 3$ & Isg-g & 6.61 & 357 & 6.13 & 3312 & 4.98 & 12 & 3.29 & 0.19 & 615 \\
\hline $\mathrm{SP} O 4$ & Isg-f & 2.15 & 254 & 1.99 & 2343 & 4.98 & 29 & 3.30 & 0.23 & 214 \\
\hline SP 05 & Isg-e & 3.38 & 523 & 2.48 & 3837 & 4.98 & 35 & 4.15 & 0.21 & 250 \\
\hline SP O6 & Isg-c & 4.41 & 472 & 2.51 & 2684 & 4.98 & 29 & 5.36 & 0.28 & 255 \\
\hline
\end{tabular}

$\rho \mathrm{s}:$ 自発飛跡密度 $\left(\times 10^{5} / \mathrm{cm}^{2}\right) . \rho \mathrm{i}:$ 誘発飛跡密度 $\left(\times 10^{6} / \mathrm{cm}^{2}\right) . \mathrm{Ns}$ : 確認した自発飛跡の総数。

$\mathrm{Ni}$ : 確認した誘発飛跡の総数.

$$
\mathrm{T}=6.12 \times 10^{-8} \times \mathrm{Ns} / \mathrm{Ni} \times \phi \quad(\mathrm{Ma})
$$

年代值の誤差は，次式により求めた。

$$
\varepsilon=\left((1 / \mathrm{Ns})^{\frac{1}{2}}+(1 / \mathrm{Ni})^{\frac{1}{2}}+(1 / \mathrm{N} \phi)^{\frac{1}{2}}\right)^{\frac{1}{2}}
$$

以上の手順により測定した結果を表 1 に示す。

\section{2 結 果}

1）Isg-c：試料から得られたジルコンは，濃桃色を 呈し，均質である。年代ヒストグラムでは，3-8Maま での広がりがみられるが，Ns-Ni 相関図ではまとまり がみられ，異質ジルコンの混在はないと考えられる。れ らから5.36Ma の年代がえられる。

2) Isg-e：ジルコンの色調・形からみて，すべての 粒子は同一起源のものと考えられる。年代ヒストグラム でも，1粒子を除いて 4-5Ma の部分に多く集まってお り，年代として $4.15 \mathrm{Ma}$ が得られた。

3）Isg-f：試料には, 白色, 桃色, 紫色のジルコン がみられ，明らかに異質ジルコンが混在している。処理

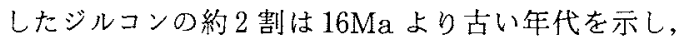
年代ヒストグラムからはずした。残りの淡桃色ジコン について, $3.30 \mathrm{Ma} の$ 年代値が求められた。

4）Isg-g：処理した粒子数は少ないが，2.5-4Ma に集中していることから，求められた年代 $3.29 \mathrm{Ma}$ は妥 当な值と考えられる。また，ジルコンのウラン含有量が $615 \mathrm{ppm}$ の高い值を示し，特異性を示している。

5）Isg-h：ジルコンは均質で色調・形が揃っている。 すべてが2.0-5.0Maに集中し，3.23Ma の年代が得ら れた。

6) Isg-pum：種々のジルコンが含まれ, 二次的な堆 皘物が混在していることが分かる。その中で淡桃色のシ ルコンが最む若い年代を示しこれにより年代を求奴。

\section{5. 考察}

\section{1 火山灰層同時間面からみた岩相の側方変化}

火山灰層による同時間面の設定によりこの地域にお
ける岩相の側方变化が明らかとなった（図 3，4）。

田麦川累層は層相変化が著しく, 田麦川累層の下部層・ 中部層・上部層は，本地域加ら南方に広く分布する泥岩 相の菖蒲䍗層(本研究では田麦川䍗層菖蒲泥岩部層と再 定義）と同時異相関係にあることが，新潟大学東䅡城地 域地質調查グループ（1987）によって報告されている。

本研究に扔いても，火山灰鍵層の追跡から，田麦川累 層下部層・中部層・上部層の層厚・層相変化や, 菖蒲泥 岩部層への側方変化が確認される。

石黒川ルート（ルートNo.48）に対して松代西部地 域の鯖石川ルート（ルートNo.11）を比較すると（図 2，3），田麦川累層下部・中部がすべて泥岩相に移行す るのが認められる。一方，田麦川ルート（ルートNo. 30）は，石黒川ルートに比較して，層相が砂岩相優勢に なり，層厚す増すことが認められる(図3)。

田麦川累層の砂岩・砂岩泥岩互層については, タービ ダイトである之考元られ（新潟大学東頚城地域地質調查 グループ，1987），上記のような層相变化は，夕ービダ イトの堆積分布範囲を示していると考えられる。

\section{2 フィッショントラック年代からみた上部新第三 系の年代}

各累層に挟まれる火山灰層のフィッショントラック年 代から，以下のような年代が考えられる。

1）田麦川累首下部： $5.5 \mathrm{Ma}$ 屯しく $5.0 \mathrm{Ma} \sim 4.5$ $\mathrm{Ma}$ 。中新統最上部加解新統最下部。

2）田麦川累層中部：4.5Ma 4.0Ma。下部鮮新統。

3）田麦川累層上部：4.0Ma 3.2Ma。下／上部鮮新 統。

4）東川累層: $3.2 \mathrm{Ma} \sim 3.0 \mathrm{Ma}$ 。下／上部鮮新統。

5）魚沼層群 : $3.0 \mathrm{Ma} \sim$ 。部鮮新統以上。

5.3 対比について

5.3.1 フィッショントラック年代からみた新潟標 準層序との対比

新潟大学東䅡城地域地質調查グループ（1987）は須川 
罢層を新潟醥準層序の椎谷層に，田麦川累層を椎谷層か ら浜忠層・西山層に，束川累層を西山層にそれぞれ対比 している。今回のフィッショントラックの年代からみて む,この対比は妥当である。

\section{3 .2 テフロソーンからみた周辺地域との対比}

（1）テフロゾーンの意味するもの

本地域の上部新第三系は，下位より9つのテフロゾー ンに分帯される。これらのゾーンは，その性質から，層 序の対比に有効であると考えられる。火山灰層が挟まれ る頻度が多いか少ないか，岩質はどうかということは， 直接的ではないにしろ周辺地域の火山活動を反映してい るものと考えられる（沢栗・黒川，1986）。したがって， 火山活動が多い時期，少ない時期，6しくは流紋岩質の 時期，安山岩質の時期と言うように，テフロゾーンは同 一の性質のまま広域にわたって，同層準として追跡され ることも多いと考えられる。このような観点から，テフ ロゾーンによる層序対比が可能であると考えられる。

(2) 小国町八石山地域との対比

沢栗 - 黑川 (1986) は，本地域北方の刚羽郡小国町地 域に括ける鮮新一更新統についてテフロゾーンを設定し， 火山活動の変遷を考察している。

本地域におけるテフロゾーンと八石山地域のテフロゾー ンとを比較すると，次のようなことが言える。

八石山地域に分布する鮮新一更新統の最下部は，下部 鮮新統と考えられるので, 本地域テフロゾーンIVより上 位に対比される。小国地域におけるテフロゾーン中には， 本地域と同様に，1つのゾーン（TNO-II）のみ安山岩 質のものが認められ，他のゾーンはいずれむ流紋岩質で ある。TNO-II は，八石山層上部にあたり，八石山火山 岩類の層準である。このことから，小国町地域の TNO IIは，本地域のテフロゾーンVIに対比される可能性が ある。テフロゾーンVIIは本地域北方の黒姫山の火山活動 によるものと考えられるので，テフロゾーンVIL TNOII は，一連の鮮新世安山岩質火山活動によるものと考え られる。

すなわち，田麦川累層上部は八石山累層上部（沢栗・ 黑川，1986）に，田麦川累層中部・下部は八石山䍗層下 部に対比される。

\section{4 浮遊性有孔虫による廨序との比較}

久保田 (1985, MS) は，本地域の石黒川流域におい て浮遊性有孔虫分析を行い, 田麦川累層中部〜東川累層 層準は, 米谷 (1978) の Globigerina pachyderma (dext.) Globorotalia orientalis Zone の中.下 部に相当し，鮮新統であるとしている。さらに，本地域 の田麦川累層中部一上部にかけては, Globorotalia inflata praeinflata MAIYA, SAITO and SATO が
多産 L, Globorotalia orientalis MAIYA, SAITO and SATO, Neogloboquadrina asanoi (MAIYA, SAITO and SATO), Neogloboquadrina kagaensis (MAIYA, SAITO and SATO) が随伴するとし，この 層準は，西山階の基底部だとされるNo. 3 Globorotalia inflata bed (米谷, 1978) であるとしている。 この層準は，フィッショントラック年代では，4.0〜4.5 $\mathrm{Ma}$ に相当する。

一方,小林ほ加(1989)では, 石黑川ルートのIsg-c 直上 (田麦川層下部)に拈いて, 底生有孔虫の Miliammina echigoensis が多産するとしている。MATSUNAGA （1963）の底生有孔虫分带加ら，Isg-c 層準が椎谷階で あるとすると，田麦川累層中部層層準〜下部層 Isg-c 層 準に西山階と椎谷階の境界があることになる。

\section{まとめ}

今回の研究により以下のことが明らかになった。

1) 新潟県東頝城地域北部高柳町一松代町周辺の上部 新第三系は，下位より須川累層・田麦川累層・東川累層・ 魚沼層群に区分される。これらは整合に累重する。田麦 川累層は，下部・中部・上部・菖蒲泥岩の各部層に区分 される。

2）鍵層亡なる火山兏層の連続加ら，田麦川累層の層 相や層厚の側方変化が明らかとなった。

3）本地域の上部新第三系は, フィッショントラック 年代から，中新統の最上部一鮮新統と考えられ，新潟標 準層序の椎谷層から西山層に対比される。

4）本地域の上部新第三系には，鍵層となる火山死層 が多く挟まれる。これら火山灰層の重鉱物組成から岩質 を推定した。推定される岩質と火山死層の挟まれる頻度 とから，本地域の上部新第三系においては，下位より9 つのテフロゾーンに分帯することができる。ほとんどの ゾーンが，流紋岩質から石英安山岩質を示すが，テフロ ゾーンVIIのが安山岩質であり，本調查地域北方に分布 する黑姫累層や八石山層（小林ほか，1989）の火砕岩類 を噴出した火山活動に由来するものと考えられる。

\section{謝 辞}

今回の研究を行うにあたり，新潟大学理学部地質鉱物 学教室の立石雅昭助教授, 同教育学部地学教室の黑川勝 己教授には，終始様々な面から御指導御援助をいただい た。新潟県横越村立横越中学校の田中 力氏, 富士通新 潟支店の武田淳子氏からは，地質調査の御援助をいただ いた。また，新潟県東䅡城郡松代町名平の武田トミエ氏 からは，宿泊の和世話をしていただいた。以上の方々に 心から御礼申し上げる次第である。 


\section{文献}

Gleadow, A. J. W., Hurford, A. J. and QUAIFE, R. D., 1976: Fission track dating of zircon, in proved techniques. Earth Planet. Sci. Lett., 33, 273-276.

菊池汃抢る・黒川勝己・ 丸山直子・落合浩代・小林㦑雄, 1984: 新潟油田地域, 灰爪層・西山層之魚沼層群の火 山灭層による対比。地質雑, 90, 101-115。

小林嚴雄・立石雅昭・安井 賢・風岡 修・黒川勝己· 油井 裕・渡边其久男, 1986: 新潟積成盆地における 西山・灭爪累層, 魚沼層群の層序と古環境。地質雑, $92,375-390$ 。

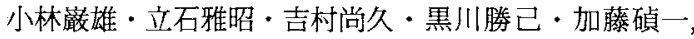
1989: 岡野町地域の地質。地域地質研究報告（5 万分 の 1 図幅)。地質調查所。

久保田尚典, 1985, MS: 新潟県阿相島地域の地質之有孔 虫化石群集, 新渴大学理学部地質鉱物学教室昭和59年 度卒業論文。

黑川勝己・沢栗美香子, 1984: 火山灰中の鉱物量比の相 関関係一魚沼層群の火山灰層を例にして一。新潟大学 教育学部紀要 (自然科学編) , 26 (1), 27-37。

米谷盛寿郎, 1978: 東北日本油田地域における上部新生 界の浮遊性有孔虫層序。日本の新生代地質, 35-36。
MATSUnAGA, T., 1963: Benthonic smaller foraminifera from the oil fields of northern Japan. Tohoku Univ., Sci. Rep., 2nd ser. (Geol.) , 35, 67-122。

新潟大学東頝城地域地質調查グループ, 1987: 新潟県東 㸚城地域の中新一鮮新統の層序。地球科学, $41,165-$ 181 。

新潟県, 1971: 新渴県東䅡城地方総合地表地質調查報告 書。24頁。

NODA, H., 1962: The geology and paleontology of the environs of Matsunoyama, Niigata Prefecture, with reference to the so-called black shale. Tohoku Univ., Sci. Rep., 2nd ser. (Geol.), $34,199-236$.

沢栗美香子・黑川勝己, 1986: 水底堆積テフラからみた 鮮新・更新世火山活動の変遷一新潟堆積盆小国町地域 の例一。地球科学, 40, 177-191.

魚沼丘陵団体研究グループ, 1983: 魚沼層群の地質。魚 沼層群, 地団研専報, $26,5-21$ 。

安井賢・小林厳雄・立石雅昭, 1983: 新潟県八石油帯・ 中央油帯南部に分布する魚沼層群の層序。地球科学, $37,22-37$ 。

吉川周作, 1976: 大阪層群の火山灰層について。地質雑, $82,497-515$ 。 